\title{
Iron Parameters as a Graft Function Indicator in Renal Transplant Recipients
}

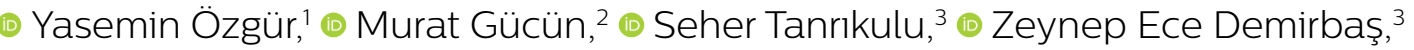

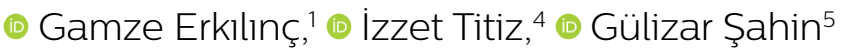

\begin{abstract}
'Department of Internal Medicine, University of Health Sciences, Kartal Dr. Lütfi Kırdar Training and Research Hospital, İstanbul, Turkey ${ }^{2}$ Department of Nephrology, University of Health Sciences, Kartal Koşuyolu Training ünd Research Hospital, İstanbul, Turkey ${ }^{3}$ Department of Internal Medicine, University of Health Sciences, Haydarpaşa Numune Training and Research Hospital, İstanbul, Turkey ${ }^{4}$ Department of General Surgery and Transplantation, Namık Kemal

University Faculty of Medicine, Tekirdağ, Turkey

${ }^{5}$ Department of Nephrology,

University of Health Sciences, Sultan Abdulhamidhan Training and Research Hospital, İstanbul, Turkey

Submitted: 24.07.2018 Accepted: 26.07.2018

Correspondence: Yasemin Özgür SBÜ, Kartal Dr. Lütfü Kırdar Eğitim ve Araştırma Hastanesi, İç Hastalıkları Kliniği, İstanbul, Turkey E-mail: dryaseminozgur@gmail.com
\end{abstract}

\section{E-mail: dryaseminozgur@gmail.com

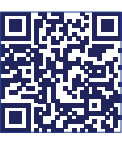

Keywords: Iron parameters; kidney transplant; posttransplant anemia; post-transplant erythrocytosis.

\begin{abstract}
Objective: For those with severe kidney disease, renal transplantation is the best treatment option when compared with dialysis methods; however, it is important to consider potential complications that may occur and the negative effects on graft survival. The aim of this study was to investigate the effects of iron parameters on the development of post-transplant anemia (PTA) and post-transplant erythrocytosis (PTE).
\end{abstract}

Methods: This retrospective study was conducted with 214 renal transplant recipients. PTA was defined as a hemoglobin $(\mathrm{Hb})$ level of $<13 \mathrm{~g} / \mathrm{dL}$ for men and $<12 \mathrm{~g} / \mathrm{dL}$ for women 6 months after transplantation, PTE was defined as an $\mathrm{Hb}$ level of $>17 \mathrm{~g} / \mathrm{dL}$ for men and $>15 \mathrm{~g} /$ $\mathrm{dL}$ for women. The remaining patients were defined as the control group.

Results: PTA developed in 79 patients (36.9\%), and PTE developed in 25 patients (II.7\%). The iron level was lower in the PTE group before the transplantation and in the first 3 months after transplantation; however, it was also determined that in the PTA group, the iron level was low at 6 and 12 months. Even though the PTA patients' transferrin saturation (TS) was rose significantly in the first month after transplant, it was observed that the TS was lower in the PTE group at all time points.

Conclusion: Even if iron levels are low before kidney transplantation in case of proper replecement is performed and graft functions are intact; anemia may improve and even polycythemia may develop. TS increased in the initial post-transplant period; it may be an early indicator of PTA and the development of graft function failure.

\section{INTRODUCTION}

Renal transplantation is undisputedly the best treatment option for those with kidney disease, but it is important to consider the complications that may occur afterwards because of the effects they may have on the survival of both the patient and the graft. Post-transplant anemia (PTA) has an incidence rate of up to $55 \%$ in renal transplant patients, and therefore it is a complication that should be watched for and meticulously treated, as it can lead to longer hospitalization, high mortality rates, and adverse effects on graft function. Post transplant-erythrocytosis (PTE) affects $8 \%$ to $15 \%$ of patients with well-preserved graft function. The aim of this study was to investigate the relationship between iron parameters and the development of PTA and PTE.

\section{MATERIAL AND METHODS}

\section{Patient population}

The records of a total of 214 patients who underwent kidney transplantation between 2003 and 2013 and who were followed-up for at least I year were retrospectively analyzed. Patients with a malignancy (renal cell carcinoma, breast cancer), chronic myeloproliferative disease, or chronic obstructive pulmonary disease were excluded. Sociodemographic data of the patients, as well as hemogram 
and biochemical parameters recorded before transplantation and at the $1^{\text {st }}$ month, $3^{\text {rd }}$ month, $6^{\text {th }}$ month, and $12^{\text {th }}$ month after transplantation, were retrieved from the hospital information registry system.

\section{Separation of patients into groups}

Patients whose hemoglobin $(\mathrm{Hb})$ level was $<13 \mathrm{~g} / \mathrm{dL}$ in males and $<12 \mathrm{~g} / \mathrm{dL}$ in females at the sixth month after transplantation were included in the PTA group. Those whose $\mathrm{Hb}$ level was $>17 \mathrm{~g} / \mathrm{dL}$ in males and $>15 \mathrm{~g} / \mathrm{dL}$ in females were categorized in the PTE group. All of the remaining patients were considered the control group.

\section{Statistical analyses}

Data analyses were performed with IBM SPSS Statistics for Windows, Version 24.0 (IBM Corp., Armonk, NY, USA). All values were shown as mean and SD, median, or percentage. Comparisons were evaluated with the Kolmogorov-Smirnov test, or a t-test for normally distributed continuous variables, and the Mann-Whitney $U$ test for continuous variables that were not normally distributed. Categorical variables were compared with a chi-square test. Continuous variables were reported as mean $\pm S D$. One-way analysis of variance (ANOVA) was used for a comparison of more than 2 groups. When the one-way ANOVA test result was significant, a post-hoc Tukey or multiple comparison test was used to determine the group that caused the significant difference. A paired samples $t-$ test was used for intra-group comparisons of continuity parameters. Pearson correlation analysis was applied for parametric data, and Spearman correlation analysis was used for non-parametric data in correlation analysis. The results were expressed in $95 \%$ confidence intervals and the level of significance was $p<0.05$.

\section{RESULTS}

A total of 214 patients were included in the study, with a mean age of 39.43 years. Of the group, 136 were male, and the mean age of the men was 40.1 years. Of the 214 patients, 79 (36.9\%) were in the PTA group, 25 (11.7\%) were in the PTE group and 110 (5I.4\%) were in the control group. The clinical characteristics of the patients are shown in Table I. The most common causes of end-stage renal disease before transplantation were hypertension (15\%), glomerulonephritis (12\%), and vesico ureteral reflux (9\%).

The mean creatinine level of the patients before transplantation in the PTA, PTE, and control group were $8.02 \pm 2.96$ $\mathrm{mg} / \mathrm{dL}, 9.23 \pm 3.37 \mathrm{mg} / \mathrm{dL}$, and $8.52 \pm 3.27 \mathrm{mg} / \mathrm{dL}$, respectively. There was no significant difference between groups $(p=0.236)$. At the $I^{\text {st }}$ month, $3^{\text {rd }}$ month, $6^{\text {th }}$ month, and $12^{\text {th }}$ month after transplantation, however, the creatinine level was significantly higher in the PTA group compared with the PTE group and the control group $(p<0.05)$.

When the glomerular filtration rate (GFR) was calculated before transplantation using the Chronic Kidney Disease
Epidemiology Collaboration equation, the mean GFR of the patients in the PTA, PTE, and control group was $9.58 \pm 8.05 \mathrm{~mL} / \mathrm{min} / 1.73 \mathrm{~m}^{2}, 6.92 \pm 3.15 \mathrm{~mL} / \mathrm{min} / 1.73 \mathrm{~m}^{2}$, and $8.07 \pm 5.42 \mathrm{~mL} / \mathrm{min} / 1.73 \mathrm{~m}^{2}$, respectively, and no significant difference was found between the groups $(p=0.125)$. The GFR value at the $1^{\text {st }}$ month, $3^{\text {rd }}$ month, $6^{\text {th }}$ month, and $12^{\text {th }}$ month after transplantation, however, was significantly lower in the PTA group than that observed in the PTE and control groups $(p<0.05)$ (Fig. I).

While statistically insignificant, it was also noted that the serum iron level was lower in the PTE group compared with the other 2 groups, both before transplantation and 6 months after transplantation $(p>0.05)$. The iron level was significantly lower in the PTA group compared with the control group ( $P$ value of 0.023 and 0.042 at 6 months and 12 months, respectively). There was no significant difference between groups in terms of total iron binding capacity (TIBC). When transferrin saturation (TS) was evaluated, the lowest level was observed in the PTE group $(p>0.05)$. The level of TS in the PTA group was lower than that of the control group before transplantation, rose in the first month after transplantation, and was lower once again in the following months ( $p>0.05)$, but was never below the mean of the PTE group (Figs. 2-4). Particularly in the first month post-transplant, the TS was more than $40 \%$ and was significantly higher than that of the other groups $(\mathrm{p}=0.039)$.

The ferritin level of the PTA group and the PTE group was statistically insignificantly lower than that of the control group before transplantation $(p=0.42 \mathrm{I})$. The decrease in the ferritin level in the PTE group after transplantation was greater than that of the PTA group, but also statistically insignificant $(p=0.159)$. After transplantation, the ferritin level of the PTA group was greater than that recorded in the control group.

The blood parathormone level was high in the PTA group and low in the PTE group before and after transplantation, but no statistically significant difference was found $(p>0.05)$. Correlation analysis of the ferritin and parathormone levels revealed a statistically significant correlation at the level of $30.8 \%(p=0.308 ; p=0.008)$.

\section{DISCUSSION}

Although the PTA frequency generally varies between $25 \%$ and $40 \%$ in the literature, it has been reported to be as high as $55 \%$. The prevalence of PTA was found to be $38.6 \%$ in a multicenter study (TRESAM) with 4263 patients in 72 centers in 16 European countries. ${ }^{[1]}$ Unal et al. ${ }^{[2]}$ followed 75 post-transplant patients for 60 months and prevalence of PTA was determined to be $49.3 \%$. In our study, the prevalence of PTA was $36.9 \%$.

PTE occurs in $8 \%$ to $15 \%$ of renal transplant recipients and may affect patients with well-preserved graft function. ${ }^{[3]}$ PTE can be defined as a persistent $\mathrm{Hb} /$ hematocrit elevation for more than 6 months without any evidence of poly- 
Table I. Clinical characteristics of the study population

\begin{tabular}{|c|c|c|c|c|c|}
\hline & $\begin{array}{l}\text { Control } \\
(n=\mid 10)\end{array}$ & $\begin{array}{c}\text { PTA } \\
(n=79)\end{array}$ & $\begin{array}{c}\text { PTE } \\
(n=25)\end{array}$ & $\begin{array}{l}\text { Total } \\
(n=214)\end{array}$ & $\mathbf{p}$ \\
\hline Gender (male) & $76(69 \%)$ & 45 (57\%) & $15(60 \%)$ & $136(64 \%)$ & NS \\
\hline Age (years) & $39.37 \pm 10.68$ & $39.77 \pm 10.98$ & $38.64 \pm 9.19$ & $39.43 \pm 10.59$ & NS \\
\hline Age at the time of transplant (years) & $33.34 \pm 10.4$ & $33.54 \pm 11.2$ & $32.84 \pm 10.1$ & $33.36 \pm 10.6$ & NS \\
\hline \multicolumn{6}{|l|}{ Type of donor } \\
\hline Living & $79(72 \%)$ & $58(73 \%)$ & $19(76 \%)$ & $156(73 \%)$ & NS \\
\hline Deceased & 31 (28\%) & $21(26 \%)$ & $6(24 \%)$ & $58(27 \%)$ & \\
\hline Age of donor (years) & $43.84 \pm 15.5$ & $49.05 \pm 15.6$ & $43.63 \pm 13.8$ & $45.75 \pm 15.5$ & 0.035 \\
\hline Age of graft (years) & $5.88 \pm 2.69$ & $6.31 \pm 2.66$ & $5.9 \pm 2.61$ & $6.02 \pm 2.65$ & NS \\
\hline Type of dialysis & & & & & NS \\
\hline HD & 77 (75\%) & $49(77 \%)$ & $21(100 \%)$ & 147 (79\%) & \\
\hline PD & $18(18 \%)$ & $7(11 \%)$ & 0 & $25(13 \%)$ & \\
\hline Preemptive transplantation & $7(7 \%)$ & $8(12 \%)$ & 0 & $15(8 \%)$ & 0.005 \\
\hline Duration of dialysis (months) & $54.63 \pm 60$ & $46.9 \pm 51.7$ & $43.05 \pm 36.9$ & $50.7 \pm 55$ & NS \\
\hline ESRD etiology & & & & & NS \\
\hline Nephrological & 55 (72\%) & 38 (7I\%) & 14 (88\%) & 107 (74\%) & \\
\hline Urological & 21 (28\%) & $15(28 \%)$ & $2(12 \%)$ & $38(26 \%)$ & \\
\hline RAS blockades $( \pm)$ & $4 \mathrm{I}(37 \%)$ & $33(42 \%)$ & $2(8 \%)$ & $76(35 \%)$ & 0.007 \\
\hline Nephrectomy ( $( \pm)$ & 7 (6\%) & $8(10 \%)$ & 0 & $15(7 \%)$ & 0.005 \\
\hline
\end{tabular}

ESRD: End-stage renal disease; HD: Hemodialysis; NS: not significant; PD: Peritoneal dialysis; PTA: Post-transplant anemia; PTE: Post-transplant erythrocytosis; RAS: Rennin angiotensin system.

cythemia vera or secondary polycythemia. The prevalence of PTE in our study was found to be $11.7 \%$.

PTA has a biphasic pattern. After surgery, most patients are anemic in the early stage. Low Hb levels in dialysis patients before transplantation affect early post-transplant $\mathrm{Hb}$ levels. An inadequate iron reserve at the time of transplantation, blood loss, frequent blood sample collections for follow-up testing, aggressive hydration (dilutional anemia), concomitant infections, and side effects of immunosuppressive drugs can trigger the development of early anemia. In our study, the mean $\mathrm{Hb}$ level of our patients (chronic kidney disease [CKD] targets of $1 \mathrm{I}-12$

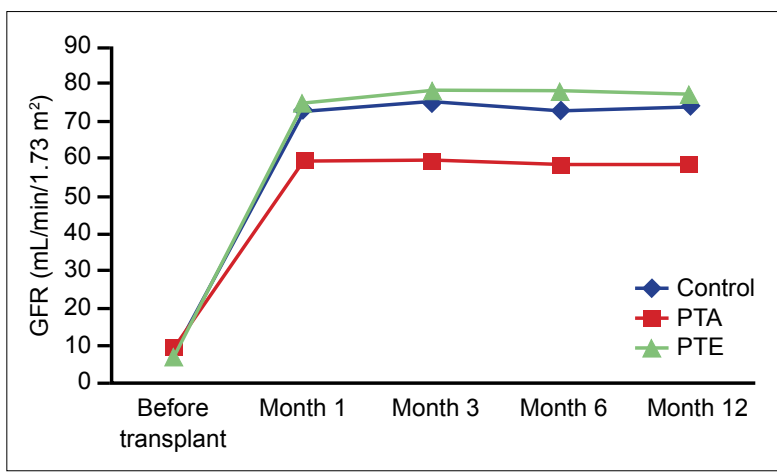

Figure 1. Change in glomerular filtration rate by group. GFR: Glomerular filtration rate; PTA: Post-transplant anemia; PTE: Post-transplant erythrocytosis. $\mathrm{g} / \mathrm{dL}$ ) was $10.8 \mathrm{~g} / \mathrm{dL}$ before transplantation and the frequency of anemia was $76.3 \%$. At the postoperative first month, the mean $\mathrm{Hb}$ level was $11.5 \mathrm{~g} / \mathrm{dL}$ and the anemia rate was $70 \%$. In the majority of renal transplant patients, the serum $\mathrm{Hb}$ level returns to normal within the first 3 to 6 months with the resolution of post-transplant complications and restoration of renal function. However, in some patients, anemia persists or may develop after transplantation. Early anemia is mostly associated with pre-transplant CKD causes and graft dysfunction (delayed graft function), whereas late anemia is associated with decreased graft renal function (chronic allograft nephropathy). The mean $\mathrm{Hb}$

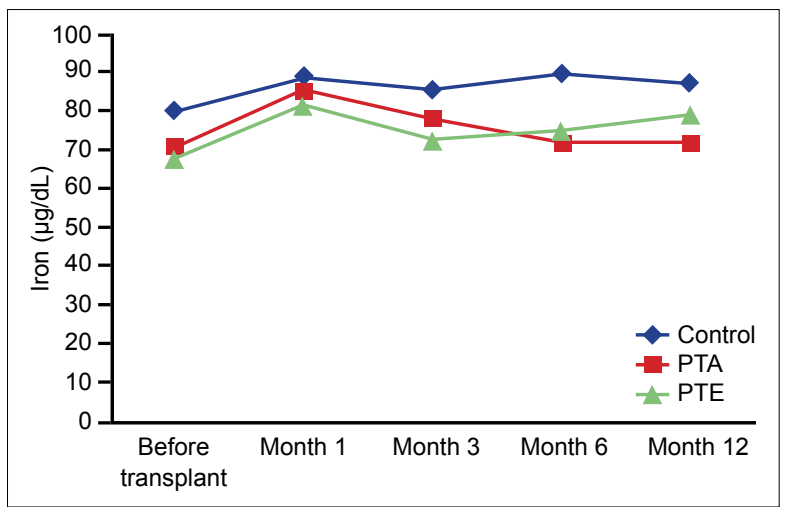

Figure 2. Iron level by group. PTA: Post-transplant anemia; PTE: Post-transplant erythrocytosis. 


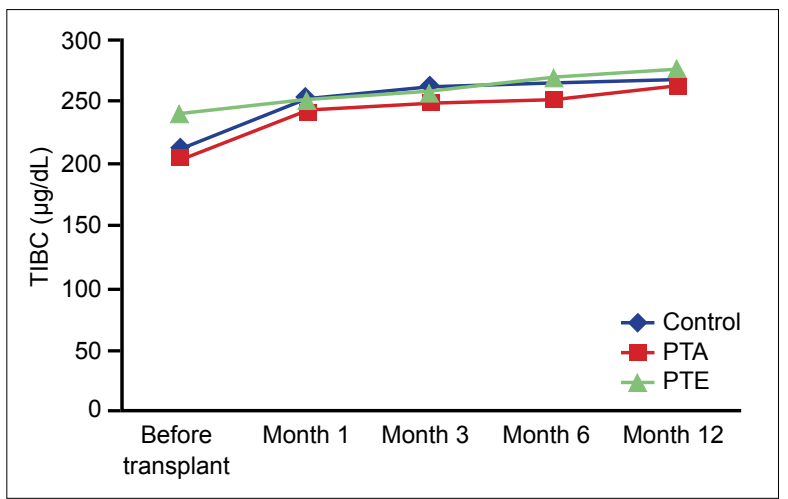

Figure 3. Total iron binding capacity by group. PTA: Post-transplant anemia; PTE: Post-transplant erythrocytosis; TIBC: Total iron binding capacity.

level of our patients was $13.3 \mathrm{~g} / \mathrm{dL}, 13.1 \mathrm{~g} / \mathrm{dL}$, and $13.5 \mathrm{~g} /$ $\mathrm{dL}$ at the $3^{\text {rd, }} 6^{\text {th }}$, and $12^{\text {th }}$ months, while the incidence of anemia was $40 \%, 36 \%, 34 \%$, respectively.

The pathogenesis of PTE is mutifactorial and not well understood. Some patients are particularly sensitive to PTE and patient-specific risk factors come to prominence. For

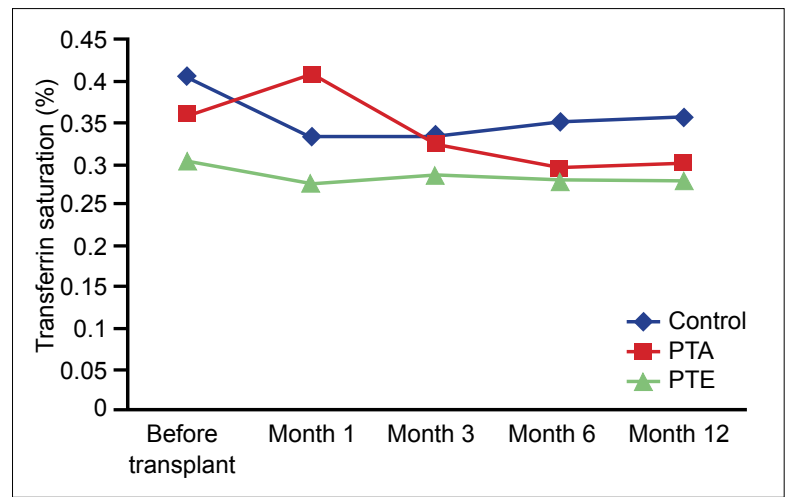

Figure 4. Transferrin saturation by group. PTA: Post-transplant anemia; PTE: Post-transplant erythrocytosis; TS: Transferrin saturation.

example, in a case report that described 2 consecutive kidney transplants, PTE developed after both transplantations. The patient had serious anemia during the 12-month period between the 2 operations. ${ }^{[4]}$ Most cases of PTE in the literature have good graft function (143-145), though various situations that increase the incidence of PTE have

Table 2. Comparative summary of laboratory parameters pre- and post-transplantation

\begin{tabular}{|c|c|c|c|c|}
\hline & \multirow{2}{*}{$\frac{\text { Control }(n=I 10)}{\text { Mean } \pm S D}$} & \multirow{2}{*}{$\frac{\text { PTA }(n=79)}{\text { Mean } \pm S D}$} & \multirow{2}{*}{$\frac{\text { PTE }(n=25)}{\text { Mean } \pm S D}$} & \multirow[t]{2}{*}{$\mathbf{p}$} \\
\hline & & & & \\
\hline \multicolumn{5}{|l|}{ Pre-transplant laboratory parameters } \\
\hline Creatinin (mg/dL) & $8.62 \pm 3.17$ & $8.13 \pm 2.80$ & $9.24 \pm 3.37$ & 0.269 \\
\hline Hemoglobin $(g / d L)$ & $10.94 \pm 2.07$ & $10.37 \pm 1.99$ & $11.74 \pm 2.47$ & $0.013^{*}$ \\
\hline Mean corpuscular volume (fL) & $90.95 \pm 9.82$ & $89.53 \pm 6.06$ & $90.41 \pm 11.92$ & 0.583 \\
\hline Iron $(\mu \mathrm{g} / \mathrm{mL})$ & $79.85 \pm 42.50$ & $70.42 \pm 36.52$ & $67.95 \pm 31.28$ & 0.227 \\
\hline Total iron binding capacity $(\mu g / d L)$ & $212.98 \pm 88.45$ & $203.46 \pm 45.77$ & $240.26 \pm 69.59$ & 0.161 \\
\hline Transferrin saturation (\%) & $0.4 I \pm 0.24$ & $0.36 \pm 0.21$ & $0.30 \pm 0.17$ & 0.14 \\
\hline Ferritin $(\mathrm{ng} / \mathrm{mL})$ & $736.04 \pm 781.37$ & $585.62 \pm 557.06$ & $568.49 \pm 496.50$ & 0.421 \\
\hline Parathyroid hormone (pg/mL) & $583.82 \pm 548.45$ & $608.13 \pm 542.80$ & $470.68 \pm 524.34$ & 0.789 \\
\hline $\operatorname{MDRD}\left(\mathrm{mL} / \mathrm{min} / \mathrm{l} .73 \mathrm{~m}^{2}\right)$ & $8.33 \pm 5.12$ & $9.59 \pm 7.16$ & $7.30 \pm 3.13$ & 0.158 \\
\hline CKD-EPI & $8.08 \pm 5.42$ & $9.59 \pm 8.06$ & $6.93 \pm 3.15$ & 0.125 \\
\hline \multicolumn{5}{|c|}{ Post-transplant $6^{\text {th }}$ month laboratory parameters } \\
\hline Creatinin (mg/dL) & $1.26 \pm 0.42$ & $1.56 \pm 0.77$ & $1.12 \pm 0.28$ & $0.001^{*}$ \\
\hline Hemoglobin $(g / d L)$ & $13.93 \pm 1.34$ & $11.21 \pm 1.59$ & $16.15 \pm 1.47$ & $0.001^{*}$ \\
\hline Mean corpuscular volume (fL) & $90.55 \pm 10.92$ & $88.63 \pm 8.00$ & $92.02 \pm 7.67$ & 0.233 \\
\hline Iron $(\mu \mathrm{g} / \mathrm{mL})$ & $89.37 \pm 49.14$ & $71.96 \pm 35.74$ & $74.67 \pm 25.79$ & $0.023^{*}$ \\
\hline Total iron binding capacity $(\mu g / d L)$ & $265.00 \pm 63.78$ & $251.81 \pm 51.10$ & $269.38 \pm 43.92$ & 0.243 \\
\hline Transferrin saturation (\%) & $0.35 \pm 0.21$ & $0.30 \pm 0.17$ & $0.28 \pm 0.09$ & 0.087 \\
\hline Ferritin $(\mathrm{ng} / \mathrm{mL})$ & $353.15 \pm 441.22$ & $415.29 \pm 452.96$ & $146.16 \pm 206.55$ & 0.182 \\
\hline Parathyroid hormone (pg/mL) & $196.34 \pm 355.80$ & $243.66 \pm 204.28$ & $|36.8| \pm 95.02$ & 0.525 \\
\hline GFR-MDRD $\left(\mathrm{mL} / \mathrm{min} / 1.73 \mathrm{~m}^{2}\right)$ & $70.39 \pm 26.76$ & $55.45 \pm 19.99$ & $74.83 \pm 22.57$ & $0.001^{*}$ \\
\hline GFR-CKD-EPI $\left(\mathrm{mL} / \mathrm{min} / \mathrm{l} .73 \mathrm{~m}^{2}\right)$ & $72.76 \pm 24.79$ & $58.17 \pm 21.97$ & $77.85 \pm 20.96$ & $0.001^{*}$ \\
\hline
\end{tabular}

CKD-EPI: Chronic Kidney Disease Epidemiology Collaboration equation; GFR: Glomerular filtration rate; MDRD: Modification of Diet in Renal Diseases equation; NS: Not significant; PTA: Post-transplant anemia; PTE: Post-transplant erythrocytosis; SD: Standard deviation. 
been mentioned. Factors thought to be involved in the pathogenesis include erythropoietin, insulin-like growth factor I, serum soluble stem cell factor, RAS, and endogenous androgens, but the most often mentioned are the production of erythropoietin and RAS stimulation.

Iron deficiency plays a major role in early PTA. A review of the literature revealed that iron parameters were not frequently evaluated, despite the prevalence of PTA. ${ }^{[5,6]}$ The available options for evaluating post-transplant iron parameters are limited. For example, elevated levels of ferritin, a well-known acute phase reactant, may be representative of an intervening disease (such as acute rejection, infection). Ferritin levels indicating iron deposits also decrease with the use of iron, but increase again with intensified iron uptake from GIS after transplantation. That is, ferritin is a non-specific measurement of the iron reserve in patients with renal transplantation and is not always associated with anemia. ${ }^{[7,8]}$ Both iron replacement therapies and blood transfusions, before and after transplantation, lead to changes in the iron parameters and may mask underlying iron deficiency anemia. The beginning of effective erythropoiese during the recovery of renal function can rapidly deplete iron deposits, ${ }^{[9]}$ and iron deficiency may develop in the first 6 months after transplantation in more than $60 \%$ of patients who have no iron deficiency prior to transplantation. ${ }^{[10]}$

In a patient with improved graft function, approximately I gram of iron is needed within 3 months after transplantation to replenish iron deposits. Iron deficiency may also be present in long-term renal transplant patients with a normal $\mathrm{Hb}$ level. In our study, the serum iron level of the PTA group was $71.96 \mu \mathrm{g} / \mathrm{mL}$, while that of the PTE group was $89.37 \mu \mathrm{g} / \mathrm{mL}$, and $74.67 \mu \mathrm{g} / \mathrm{mL}$ for the control group. The serum iron level of the PTA and PTE groups was significantly lower than that of the control group $(p=0.023)$. Similarly, the PTA group mean TIBC was $251.81 \mathrm{mcg} / \mathrm{dL}$, while it was $269.38 \mathrm{mcg} / \mathrm{dL}$ in the PTE group and 265.00 $\mathrm{mcg} / \mathrm{dL}$ in the control group. The comparison of mean TS revealed $30 \%$ in the PTA group, $28 \%$ in the PTE group, and $35 \%$ in the control group. In patients with PTA, a low serum iron level and a low TIBC may be seen accompanying iron deficiency anemia, poor graft function, and anemia of chronic disease. In patients with PTE, a low serum iron level, and a high TIBC may be caused by increased iron deficiency anemia due to rapid depletion of iron deposits with increased erythropoiesis. Restoration of endocrine functions after transplantation and regular menstruation in women may contribute to the development of iron deficiency. In a study after transplantation, most female patients had more anemia than the male patients. In our study, we observed that among the 78 female patients $43 \%$ had PTA and $12 \%$ had PTE. Among the 136 male patients, PTA was seen in $33 \%$ and PTE in II\%. Although not statistically significant, we found that PTA developed more frequently in our female patients. This has been attributed to the resumption of menstruation with improved kidney function and the general tendency of women to have ane- mia. ${ }^{[I]}$ In some other studies, the prevalence of anemia was found to be higher in males. ${ }^{[12]}$

PTA has been associated with chronic fatigue, decreased exercise capacity, cognitive weakness, and a deterioration of quality of life. In addition to these symptoms seen in PTA, complications observed after the surgery are also important. There are several conflicting studies of late PTA related to graft and patient survival. ${ }^{[13]}$

In cases of PTE, about $60 \%$ of patients suffer with headaches, numbness, and dizziness; $10 \%$ to $30 \%$ have a thromboembolic event; and $1 \%$ to $2 \%$ have increased erythropoiesis that does not regress spontaneously. Left untreated, complications can lead to death. Thromboembolic events can occur in both venules and arteries, and may appear as thrombosis, thrombophlebitis, small vessel occlusion, and pulmonary embolism. ${ }^{[14,15]}$

\section{CONCLUSION}

In our study, the frequency of PTA and PTE was determined to be $36.9 \%$ and $11.7 \%$, respectively, at the I-year follow-up. PTA was significantly associated with a high creatinine level, low creatinine clearance, low serum iron level (especially after 6 months), and high TS in the early posttransplant period. If the patient's iron level is low before the kidney transplantation, maintenance of graft functions and the proper iron replacement can lead to resolution of anemia. It can even progress to polycythemia. If TS increases in the early post-transplant period, it may be an early indicator of graft dysfunction due to the development of PTA.

\section{Ethics Committee Approval}

Retrospective study.

Peer-review

Internally peer-reviewed.

Authorship Contributions

Concept: Y.Ö., M.G.; Design: Y.Ö., S.T.; Data collection \&/ or processing: Y.Ö., M.G.; Analysis and/or interpretation: Y.Ö.; Literature search: Y.Ö., Z.E.D.; Writing: Y.Ö., G.E.; Critical review: I.T., G.Ş.

Conflict of Interest

None declared.

\section{REFERENCES}

1. Vanrenterghem Y, Ponticelli C, Morales JM, Abramowicz D, Baboolal K, Eklund B, et al. Prevalence and management of anemia in renal transplant recipients: a European survey. Am J Transplant 2003;3:835-45. [CrossRef]

2. Unal A, Sipahioglu MH, Akcakaya M, Tokgoz B, Sav T, Oymak O, et al. An underappreciated problem in renal transplant recipients: anemia. Transplant Proc 2008;40:1399-403. [CrossRef]

3. Gaston RS, Julian BA, Curtis JJ. Posttransplant erythrocytosis: an enigma revisited. Am J Kidney Dis 1994;24:1-11. [CrossRef]

4. Danovitch GM, Jamgotchian NJ, Eggena PH, Paul W, Barrett JD, 
Wilkinson A, et al. Angiotensin-converting enzyme inhibition in the treatment of renal transplant erythrocytosis. Clinical experience and observation of mechanism. Transplantation 1995;60:132-7. [CrossRef]

5. Muirhead N. Erythropoietin and renal transplantation. Kidney Int Suppl 1999;69:S86-92. [CrossRef]

6. Foley RN, Parfrey PS, Morgan J, Barré PE, Campbell P, Cartier P, et al. Effect of hemoglobin levels in hemodialysis patients with asymptomatic cardiomyopathy. Kidney Int 2000;58:1325-35. [CrossRef]

7. Teruel JL, Lamas S, Vila T, Hernandez RM, Quereda C, Marcen R, et al. Serum ferritin levels after renal transplantation: a prospective study. Nephron 1989;51:462-5. [CrossRef]

8. Miles AM, Markell MS, Daskalakis P, Sumrani NB, Hong J, Sommer BG, et al. Anemia following renal transplantation: erythropoietin response and iron deficiency. Clin Transplant 1997;11:313-5.

9. Moore LW, Smith SO, Winsett RP, Acchiardo SR, Gaber AO. Factors affecting erythropoietin production and correction of anemia in kidney transplant recipients. Clin Transplant 1994;8:358-64.

10. Zheng S, Coyne DW, Joist H, Schuessler R, Godboldo-Brooks A,
Ercole P, et al. Iron deficiency anemia and iron losses after renal transplantation. Transpl Int 2009;22:434-40. [CrossRef]

11. Drüeke TB, Locatelli F, Clyne N, Eckardt KU, Macdougall IC, Tsakiris D, Burger HU, et al; CREATE Investigators. Normalization of hemoglobin level in patients with chronic kidney disease and anemia. N Engl J Med 2006;355:2071-84. [CrossRef]

12. Saito S, Fujiwara T, Sakagami K, Matsuno T, Tanaka N. Anemia following renal transplantation. Transplant Proc 1998 ve 3025, 30.

13. Winkelmayer WC, Chandraker A, Alan Brookhart M, Kramar R, Sunder-Plassmann G. A prospective study of anaemia and long-term outcomes in kidney transplant recipients. Nephrol Dial Transplant 2006;21:3559-66. [CrossRef]

14. Wickre CG, Norman DJ, Bennison A, Barry JM, Bennett WM. Postrenal transplant erythrocytosis: a review of 53 patients. Kidney Int 1983;23:731-7. [CrossRef]

15. Kessler M, Hestin D, Mayeux D, Mertes PM, Renoult E. Factors predisposing to post-renal transplant erythrocytosis. A prospective matched-pair control study. Clin Nephrol 1996;45:83-9.

\section{Böbrek Nakli Olan Hastalarda Greft Fonksiyon Göstergesi Olarak Demir Parametreleri}

Amaç: Böbrek nakli, diyaliz yöntemlerine kıyasla en iyi tedavi seçeneği olmakla birlikte sonrasında meydana gelen komplikasyonlar greft sağ kalımına olumsuz etkileri nedeniyle önemlidir. Bu çalışmanın amacı, demir parametrelerinin post transplant anemi (PTA) ve post transplant eritrositoz (PTE) gelişimi üzerine etkilerini araştırmaktır.

Gereç ve Yöntem: Bu retrospektif çalışmamıza böbrek nakli yapılmış $2 । 4$ hasta dahil edildi. Nakil sonrası altıncı aydan sonra bakılan hemoglobin düzeyleri ortalaması erkeklerde $<13 \mathrm{~g} / \mathrm{dL}$, kadınlarda $<12 \mathrm{~g} / \mathrm{dL}$ olanlar PTA; yine hemoglobin düzeyleri erkeklerde $>17 \mathrm{~g} / \mathrm{dL}$, kadınlarda ise $>15 \mathrm{~g} / \mathrm{dL}$ üstünde olan hastalar PTE; geri kalan tüm hastalar da kontrol grubu olarak tanımlandı.

Bulgular: İki yüz on dört hastanın 79'unda (\%36.9) PTA, 25'inde (\%।I.7) PTE geliştiği görüldü. Demir düzeylerinin nakil öncesinde ve nakil sonrası ilk üç ayda PTE grubunda düşük tespit edilmesine rağmen altıncı ve 12. ayda PTA grubunda düşüş gösterdiği tespit edildi. Transferrin satürasyonlarına (TS) ise nakil sonrası birinci ayda PTA grubunda anlamlı olarak yükselmesine rağmen, diğer tüm aylarda PTE hastalarında düşük seyrettiği tespit edildi.

Sonuç: Böbrek nakli yapılmadan önce demir düzeyi düşük olsa dahi uygun replasman yapıldığı takdirde greft fonksiyonları sağlamsa eğer anemi düzelecek hatta polisitemi dahi gelişebilecektir. Nakil sonrası erken dönemde transferrin satürasyonları yükseliyorsa PTA'nın habercisi dolayısıyla greft fonksiyon bozukluğu gelişebileceğinin erken göstergesi olabilir.

Anahtar Sözcükler: Böbrek nakli; demir parametreleri; post-transplant anemi; post-transplant eritrositoz. 